\title{
ВОЗМЕЩЕНИЕ УЩЕРБА ПОСТРАДАВШИМ МЕЖДУНАРОДНЫМИ УГОЛОВНЫМИ ТРИБУНАЛАМИ
}

\begin{abstract}
Аннотация. В статье рассматривается вопрос возмещения ущерба пострадавщим от международного преступления международными трибуналами (Международным судом и международными трибуналами ad hoc). Рассматривается также деятельность и функиии Трастового фонда Международного уголовного суда в интересах пострадавщих от преступлений в пределах юрисдикиии МУС.Автор констатирует, что существует практически всеобщее согласие относительно того, что жертвы серьезных международных преступлений имеют право на возмещение. Разногласия вызывает право, $и$ особенно объем этого права, международных уголовных трибуналов на решение вопроса о предоставлении пострадавшим возмещения. Так, международные уголовные трибуналь аd hос и Международный уголовный суд подходят к вопросу о возмещениях очень по-разному. Действующие ныне международные уголовные трибуналы аd hoc не выносят постановлений о возмещении пострадавшим. Трибуналь не могут предоставить пострадавщим компенсации, и не занимаются реституцией собственности. Международный уголовный суд, с другой стороны, способен обеспечивать пострадавших компенсаииями, то есть у него несколько гражданско-правовой подход к вопросу о возмещениях. Суд может решить о предоставлении возмещения, а пострадавшим предоставлены права участия в процессе в том, что касается рассмотрения вопроса о возмещении.
\end{abstract}

Ключевые слова: международное право, уголовное право, международный уголовный суд, международные уголовные трибуналь, Трастовый фонд, ущерб, потерпевший, возмещение, компенсация, репарация. Abstract: The article concerns the issues of compensation of harm to the victims of international crime by international criminal tribunals (by the International Criminal Court and the ad hoc criminal tribunals. The author also evaluates activities and functions of the Trust Fund of the International Criminal Court in the interests of victims of crimes within the scope of jurisdiction of the ICC. The author states that there is basically universal agreement regarding the fact that the victims of grave international crime have a right for the compensation of harm. However, the attitudes of the ICC and the ad hoc criminal tribunals to the compensation issues differs. The currently active international criminal tribunals ad hoc do not make resolution on compensation to the victims. The tribunals cannot provide compensation for the victims and do not provide proprietary restitution. The International Criminal Court is capable of provision of compensation to the victims, so it does have a somewhat civil law approach to compensation. The court may decide on the compensation issues, and the victims have a right to take part in the process in respect of compensation issues.

Keywords: international law, criminal law, international criminal court, international criminal tribunals, the Trust Fund, harm, victim, compensation, retribution, reparation.

1. Вопрос о возмещении ущерба пострадавшим в работе международных уголовных трибуналов ad hoc

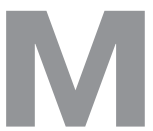

еждународные уголовные трибуналы занимаются только преступлениями против мира и безопасности человечества, то есть ответственностью физических лиц за совершение определенных преступлений ${ }^{1}$.

${ }^{1}$ МТБЮ ст.1 и 6, МТР ст.1 и 5, ССС-Л ст.1, МУС ст.25.
Анализируя права потерпевших на возмещение необходимо помнить, что трибуналы не имеют компетенции на решение вопросов об ответственности государств. Трибуналы не могут наложить санкции на государство в пользу отдельного потерпевшего или принять постановление о репарациях против государства ${ }^{2}$.

Статуты трибуналов ad hoc хранят молчание относительно возмещений потерпевшим, может

\footnotetext{
${ }^{2}$ CM. UN Doc. S/2000/1063, Appendix, par. 16.
} 
быть, просто из-за слишком больших масштабов преступлений, и потенциально слишком большого числа заявителей ${ }^{3}$.

Однако в резолюции Совета Безопасности, которой был принят Статут Трибунала по Югославии, содержится положение о том, что деятельность Международного трибунала должна осуществляться не ущемляя права жертв добиваться соответствующими способами компенсации за ущерб, причиненный в результате нарушений международного гуманитарного права ${ }^{4}$.

Эта идея развита в Правилах трибуналов. Общее для них Правило 106 устанавливает, что Секретарь передает компетентным властям соответствующих государств приговор, в котором обвиняемый признан виновным в совершении преступления, нанесшего ущерб потерпевшему; на основании национального законодательства потерпевший может обратиться с иском в национальный суд или иной компетентный орган для получения компенсации. В том же Правиле 106 установлено, что для целей компенсации решение Международного трибунала окончательно и обязательно в том, что касается уголовной ответственности лица, обвиненного в нанесении ущерба. Это значит, что потерпевший, уже после международного разбирательства, должен подавать гражданский иск о возмещении ущерба в другой суд. При этом не установлено, каким образом и от кого должна истребоваться компенсация. Конечно, нет никакой уверенности в том, что в национальных системах правосудия все эти правила уже разработаны и действуют.

В решениях по делам Srebrenica в Палате по правам человека в Боснии и Герцеговине содержалось несколько ссылок на дела Krstić and Erdemović, рассматривавшиеся в Трибунале по Югославии. Обвинения в этих делах были предъявлены Сербской Республике, а не Крстичу или Эрдемовичу, а решение о репарациях основывалось на том, что Республика не предоставила и не сделала доступной информацию, которую запрашивали истцы с целью найти своих близких ${ }^{5}$. В дискуссиях во время судебного разби-

\footnotetext{
${ }^{3}$ Heikkilä M. Op.cit, p.175.

${ }^{4}$ UN Doc. S/RES/827 (1993), par. 7.

${ }^{5}$ Human Rights Chamber for Bosnia Herzegovina, cases CH/01/8365 ei al.
}

рательства было заявлено: «Правило 106 ясно отсылает вопрос о компенсациях в юрисдикцию национального суда и тем самым создает механизм, с помощью которого приговор, вынесенный Трибуналом, может быть передан властям государства, чтобы стать основой для принятия мер по национальному праву. Вряд ли данное положение приведет к существенным результатам в ближайшем будущем» ${ }^{6}$.

Впоследствии судьи двух трибуналов представили доклад по этому вопросу, в котором содержался важный вывод: в международном праве действительно существует право на компенсации для потерпевшего от преступления ${ }^{7}$ Прокурор Трибуналов Карла дель Понте выдвинула два предложения: относительно компенсаций потерпевшим и относительно их участия в процессе. Пленум судей решил поручить Комитету по Регламенту при содействии Секретариата изучить эти предложения и сделать рекомендации судьям. Окончательный текст доклада был передан Совету Безопасности ООН в сентябре 2000г. ${ }^{8}$

Таким образом, главным вопросом для судей стал вопрос о порядке имплементации права на возмещение 9 . Возможен был следующий вариант: требования компенсации должны представляться трибуналу как дополнение к уголовному делу, но это бы потребовало внесения значительных изменений в процесс в трибуналах ${ }^{10}$. Кроме того, такая система может иметь очень неблагоприятные последствия в виде сильного увеличения нагрузки на различные органы трибуналов продолжительности рассмотрения исков; потребует значительных расходов и поведет к неравноправию среди пострадавших ${ }^{11}$. Поэтому, заключили судьи, следует отдать предпочтению таким методам возмещения, которые не опираются на структуру трибуналов, как, например, международные компенсационные комиссии ${ }^{12}$.

\footnotetext{
${ }^{6}$ UN Doc. S/2000/1063, Appendix, par. 45.

${ }^{7}$ UN Doc. S/2000/1063, Appendix, par. 21.

${ }^{8}$ UN Doc. S/2000/1063, Appendix and ICTY Doc. Press Releases JL/P.I.S./518-e and JL/P.I.S./528-e.

${ }^{9}$ UN Doc. S/2000/1063, Appendix, par. 22.

${ }^{10}$ UN Doc. S/2000/1063, Appendix, pars. 23 and 26.

${ }^{11}$ UN Doc. S/2000/1063, Appendix, pars. 33-41.

${ }^{12}$ UN Doc. S/2000/1063, Appendix, pars. 42-48.
} 
Президент Трибунала по Югославии Жорда считал также, что средством обеспечения потерпевших компенсациями могли бы стать национальные согласительные комиссии. Он считал, что такие комиссии играют важную роль в решении вопросов репараций внутри государств. Заслушав показания многих потерпевших, комиссия могла бы предложить политическим властям репарации в той или иной форме, так чтобы при этом учитывался коллективный характер ущерба, нанесенного военными действиями. По его мнению, полезно было бы сформировать образовательные программы, создатьмемориальные музеи или архивы фильмов, которые могли бы быть использованы в пропагандистской работе. Необходим также компенсационный фонд, который комиссия могла бы использовать для нужд населения, пострадавшего от конфликта ${ }^{13}$.

Судьи Трибунала для Руанды также пришли к выводу о том, что система компенсаций, если бы ею распоряжался Трибунал, «сильно помешала бы повседневной работе Трибунала, и это было деструктивным фактором в исполнении основной его функции» и что «существуют иные, более скорые и простые методы» предоставления пострадавшим компенсаций ${ }^{14}$. Среди таких иных методов названы:

- создание специального агентства в рамках $\mathrm{OOH}$, которое бы управляло схемой компенсаций или трастовым фондом;

- подобная же схема, управляемая другим каким-либо агентством или международной организацией;

- структура, которая бы могла работать совместно с вышеуказанными опциями, и которая позволила бы Трибуналу просто осуществлять ограниченные полномочия относительно распоряжений об уплате сумм из трастового фонда потерпевшим, фактически присутствующим в качестве свидетеля в деле ${ }^{15}$.

В октябре 2002г. Президент Трибунала по Руанде Н.Пиллей, выступая в Генеральной Ассамблее, решительно призвал ООН принять меры к обеспечению жертв руандийского гено-

\footnotetext{
${ }^{13}$ ICTY Doc. Press Release JL/P.I.S./591-e.

${ }^{14}$ UN Doc. S/2000/1198, Annex, pars. 4-5; UN Doc. A/57/163, pars. $90-91$.

${ }^{15}$ UN Doc. S/2000/1198, Annex, par. 15.
}

цида компенсациями ${ }^{16}$, а Секретарь Руандийского трибунала А.Денг обратилась к мировому сообществу с призывом создать специальный фонд для жертв геноцида ${ }^{17}$.

Следует отметить, что судьи трибуналов не одобрили предложение Прокурора Карлы дель Понте о том, что потерпевшие должны получать в возмещение деньги от осужденного лица ${ }^{18}$.

Таким образом, ни уставы трибуналов, ни из правила процедуры не предусматривают предоставление потерпевшим компенсаций. Однако в уставах, подобно уставам трибуналов, созданных после второй мировой войны для наказания военных преступников Германии и Японии ${ }^{19}$, предусмотрена лишь реституция, то есть, возвращение собственности.

Реституция признается и в документах трибуналов. В соответствии со ст.24(3) Устава Трибунала для Югославии и ст.23(3) Трибунала для Руанды Судебная палата вправе, кроме тюремного заключения, приговорить также к возвращению собственности, присвоенной в результате преступного поведения, ее законным владельцам ${ }^{20}$. Общее Правило 105 устанавливает, что Судебная палата, по требованию Прокурора или по собственной инициативе, может провести специальные слушания для определения вопросов реституции собственности или вырученных за нее доходов, и постановить о временных мерах защиты и сохранения собственности на это время, как она сочтет нужным. Такое определение может распространяться на такую собственность или вырученные за нее доходы, даже если они находятся в руках третьего лица, никак не связанного с преступлением, в котором обвиняемый признан виновным. Согласно Правилу 105(C), такое третье лицо может быть вызвано в суд, и ему может быть предоставлена возможность защищать свое право на данную собственность. Если у Следственной палаты будет возможность установить законного владельца, она примет

\footnotetext{
${ }^{16}$ ICTR Doc. Press Release ICTR/INFO-9-2-326.

${ }^{17}$ ICTR Doc. Press Release ICTR/INFO-9-2-343.

${ }^{18}$ ICTY Doc. Press Release JL/P.I.S./542-e; UN Doc. A/55/517, par. 41.

19 Устав Нюрнбергского трибунала, ст.28 и Распоряжение Контрольного совета № 10, ст.II:3.

${ }^{20}$ См. также ст. 19(3) Статута Суда для Сьерра-Леоне.
} 
постановление о реституции, если же нет - она известит компетентные национальные власти и потребует установления. Согласно «Примерным указаниям об имплементации Резолюции 827» $2^{21}$ постановление Международного трибунала, требующее конфискации или возвращения любой собственности или доходов от ее продажи исполняется в соответствующем государстве в соответствии с национальным законодательством.

В литературе указывается на то, что случаи реституции по решению трибуналов пока не встречались ${ }^{22}$. В решении по делу Musema, которое рассматривалось Трибуналм для Руанды, Судебная палата, ссылаясь на Правило 88, указала, что обвинительный акт должен содержать обвинение в незаконном отъеме собственности, прежде чем трибунал $a d$ hoc может принять постановление о реституции ${ }^{23}$.

Наконец, потерпевшие, выступающие в заседании трибунала, могут получить одну, весьма ограниченную форму репараций, а именно денежное пособие для свидетеля. Отдел по вопросам потерпевших и свидетелей Трибунала для Югославии подчеркнул в своем ежегодном докладе, что свидетели не должны нести финансовое наказание за свидетельство ${ }^{24}$. Потерпевший, выступающий свидетелем в Трибунале для Югославии, имеет право получить:

1. пособие для посещения (в возмещение заработной платы и потраченного времени);

2. компенсация чрезвычайных расходов из-за свидетельских показаний;

3. оплата транспорта, жилья и питания;

4. оплата питания;

5. случайные расходы на разумные персональные затраты свидетелей, которые нуждаются в недолгом проживании;

6. деньги на подневное содержание;

7. возмещение расходов на уход за детьми ${ }^{25}$.

${ }^{21}$ ICTY Doc. Tentative Guidelines for National Implementing Legislation of United Nations Security Council Resolution 827 of 25 May 1993

${ }^{22}$ Heikkilä M. Op.cit.,p.178.

${ }^{23}$ ICTR. Musema Decision of 17 March 1999,pars. 10-11.

${ }^{24}$ UN Doc. A/50/365, par. 116 and UN Doc. A/51/292, par. 120.

${ }^{25}$ ICTY Doc. IT/200, Articles 7-14. См. также: UN Doc. $\mathrm{A} / 51 / 292$, par. 120 и UN Doc. A/52/375, par. 97.
Относительно свидетелей в Трибунале для Руанды было решено: «Затраты на поездки свидетелей состоят из стоимости проездных документов, проживания в Кигали, а также подневные расходы», и что «необходимо положение о том, что должны оплачиваться охрана и поддержка. Сюда входят транспортные расходы, деньги для сопровождающего лица, затраты на уход за ребенком, оплата медицинских услуг, одежда для свидетелей, компенсация за утерянные рабочие часы и стоимость питания» ${ }^{26}$.

Учитывая те потери, которые могут быть причинены пострадавшему преступлением, все перечисленные расходы кажутся ничтожными.

2. Вопрос о возмещении пострадавшим в работе Международного уголовного суда

Статут Международного уголовного суда предусматривает возмещение пострадавшим, включая компенсации; порядок которых основывается на судебном процессе государств различных правовых систем ${ }^{27}$. Однако в международном плане Международный уголовный суд - это единственный источник процессуальных норм, касающихся возмещения потерпевшим в международном праве.

Центральное место занимает ст.75 Римского статута. В ней говорится о том, что Суд может, по просьбе или, в исключительных случаях, по своей собственной инициативе, принять решение о предоставлении возмещения, включая реституцию, компенсацию и реабилитацию. Правило 94 уточняет, что в письменной просьбе, направляемой потерпевшим Суду, должны содержаться:

- личные данные заявителя;

- $\quad$ описание ущерба, убытков или нанесенного вреда;

- место и время происшествия;

- насколько возможно, местонахождение и личные данные лица, которого потерпевший считает ответственным за причинение ущерба, убытков или нанесенного вреда;

- описание затребуемых имущества и вкладов;

\footnotetext{
${ }^{26}$ UN Doc. A/56/497, pars. 56 и 59. См. также: UN Doc. $\mathrm{A} / 55 / 512$, pp. 25 (par. 53) и 55 (par. 81).

${ }^{27}$ UN Doc. S/2000/1063, Appendix, par. 12.
} 
- требование компенсации;

- требование реабилитации или иных форм возмещения;

- любая полезная информация.

Поступившая просьба о возмещении рассматривается в специальном заседании по этому вопросу либо назначается дополнительное слушание по поводу приговора ${ }^{28}$. Если же Суд собирается обсуждать вопрос о возмещениях по собственной инициативе, Секретарь извещает об этом потерпевших. Если потерпевший в ответ на это, представляет свою просьбу о возмещении, такая просьба получает такой же статус, как первоначальная просьба о возмещении. Потерпевший, в ответ на информацию Секретаря, может также просить Суд не выносить постановление о возмещении, и в этом случае Суд прекращает вынесение отдельного постановления на этот счет. Однако, отдельный потерпевший не может помешать вынесению постановления Суда, о коллективном возмещении, инициированного самим Судом.

В обязанности Секретаря Суда входит информирование лиц, затронутых просьбой о возмещении и соответствующими действиями Суда. Секретарь постоянно информирует лиц, против которых направлен иск о возмещении, и по мере возможности, также потерпевших, заинтересованных лиц и государства. Другими словами, Секретарь принимает все необходимые меры к обеспечению публичности процесса о возмещениях, что дает возможность всем затронутым лицам, в том числе добросовестным приобретателям собственности, заявить о своих правах.

Важно отметить, однако, что информирование третьей стороны обязательно лишь в той степени, в какой оно возможно ${ }^{29}$. Именно Суду принадлежит исключительное полномочие определять, получит ли потерпевший возмещение на основании решения Суда. Ст.75 Статута устанавливает, что Суд :

- определяет в своем решении масштабы и размер любого ущерба, убытков и вреда, причиненных потерпевшим;

- $\quad$ заявляет о принципах, на основании которых он действует.

\footnotetext{
${ }^{28}$ Ст.76 Римского статута и Правило 143.

${ }^{29}$ Правила 94(2) и 95(1).
}

Дона-Каттэн замечает в этой связи: «Суд обязан установить принципы, относящиеся выплате возмещения. Общие положения о праве на реституцию, компенсации и реабилитацию могут быть включены в приговор, без определения конкретных мер реституции или размеров компенсации. В делах с большим числом пострадавших названные вопросы могут стать предметом регулирования ad hoc, принимаемого национальными властями, или в сотрудничестве с госудрствами, где находится спорное имущество» ${ }^{30}$.

Правилами предусмотрено, что Суд может назначить в помощь себе экспертов для определения объема любого ущерба, потерь или вреда, а также установить надлежащие способы репараций ${ }^{31}$.

Суд может постановить о выплате репараций на индивидуальной, или, если он считает походящим, на коллективной основе, или и то, и другое ${ }^{32}$. Значит, отдельный потерпевший может получить возмещение и сам и по себе и в составе группы.

Одна из трудных задач, стоящих перед Судом - определение надлежащего возменещения. Т.ван Бовен отмечает в Докладе Комиссии $\mathrm{OOH}$ по правам человека: «Очевидно, что грубые нарушения прав человека и основных свобод, совершаемые в массовом порядке, по самой своей природе невосполнимы. В таких случаях никакое средство возмещения не может быть пропорциональным тяжелым травмам, которые наносятся жертвам» ${ }^{33}$.

В Международном уголовном суде постановлению о возмещении должен предшествовать приговор ${ }^{34}$.

С точки зрения потерпевшего несправедливо лишать их возмещения в том случае, если преступник не обнаружен и не осужден.В рамках работы Трибунала для Руанды была составлена Программа восстановительного правосудия, в которой, наоборот, сказано, что даже в тех случаях, когда нарушитель не найден, могут быть

\footnotetext{
${ }^{30}$ Donat-Cattin D. Article 75 - Reparations to Victims// Triffterer O. Commentary on the Rome Statute of the International Criminal Court: Oserver's Notes Article by Article. 1999, pp. 969-970.

${ }^{31}$ Правило 97(2).

${ }^{32}$ Правило 97 (1).

${ }^{33}$ UN Doc. E/CN.4/Sub.2/1993/8, p. 53 (par. 131).

${ }^{34}$ Ст. 75(2) Римского статута.
} 
потерпевшие. В Трибунале для Югославии в ходе дискуссии о возмещениях потерпевшим судьи заявляли, что какой бы метод обеспечения компенсаций не был избран, следует признать, что в некоторых отношениях несправедливо лишать многих потерпевших от преступлений в бывшей Югославии, лишать их возможного возмещения ${ }^{35}$.

Необходимо отметить, что и в Римском статуте ст.75 (6) устанавливает, что ничто не должно толковаться как ущемляющее права потерпевших в соответствии с национальным или международным правом. Отсюда можно сделать вывод о том, что в принципе в Статуте заложена возможность получения потерпевшим возмещения не от Суда, а из других источников.

Статут и Правила оставляют без регулирования многие детали процесса возмещения, в частности, вопросы доказывания факта потери или нанесения ущерба, статус беженца или бездомного, или лишенного медицинского обслуживания.

Римский статут предоставляет Суду гибкие полномочия в части предписания надлежащего возмещения для пострадавших. Понятие «возмещение» не получило ясного определения ни в Статуте, ни в Правилах, статья 75 лишь указывает, что данным термином охватываются реституция, компенсации и реабилитацию.

В этой недоработке определения отразились, с одной стороны, противоречия относительно того, что такое надлежащее возмещение, а с другой попытка дать суду возможность самому разработать обычный порядок определения возмещения.

В целях получить содействие в решении вопросов относительно типов и способов возмещения суд вправе назначить экспертов ${ }^{36}$. Однако необходимо подчеркнуть, что суд может выносить решение о выплате возмещений только в отношении обвиненных индивидов, а не организаций или, например, государств. Такое решение может быть вынесено непосредственно в адрес обвиняемого, или косвенно, через трастовый фонд ${ }^{37}$. Суд может также распорядиться о том, чтобы денежные суммы или иное имущество, собранные путем выплаты штрафов или конфискации,

\footnotetext{
${ }^{35}$ UN Doc. S/2000/1063, Appendix, par. 41.

${ }^{36}$ Правило 97 (2).

${ }^{37}$ Ст.75 (2) Римского статута и Правило 98.
}

были переданы Фонду ${ }^{38}$. Государства-участники Римского статута обязаны сотрудничать в исполнении постановлений о возмещении ${ }^{39}$.

Действие системы возмещений, основанной на выплатах потерпевшим со стороны обвиняемых, зависит в высшей степени от возможности получить доступ к средствам и имуществу обвиняемых, а также от возможности предотвратить избавление от этого имущества или передачи его другому лицу.

Статья 57(3)(е) Римского статута предоставляет Доследственной палате такие необходимые полномочия, устанавливая, что эта палата вправе, в случае выдачи ордера на арест или повестки, опираясь на убедительность доказательств, а также учитывая права затронутых сторон, просить содействия со стороны государств в принятии защитительных мер с целью конфискации, особенно для возмещения основных доходов потерпевших ${ }^{40}$. Другое положение, нацеленное на обеспечение наличия фондов в пользу потерпевших, - это статья 75(4), в которой говорится о том, что суд может после вынесения приговора определить наличие необходимости искать содействия государств в идентификации, обнаружении или замораживании авуаров, имущества или иных доходов от преступления с целью фактического возмещения.

Наконец, статья 79(2) предписывает, что суд может распорядиться о том, чтобы деньги и иное имущество, полученные от штрафов или конфискации, были переданы Трастовому фонду. Данное положение основано, очевидно, в частности, на том, что в Проекте статей, составленном Комиссией международного права в 1994 году, говорилось: «Выплаченные штрафы могут быть переданы, по распоряжению Суда, трастовому фонду, образованному Генеральным секретарем $\mathrm{OOH}$, в пользу жертв преступления» ${ }^{41}$. С другой стороны, Трастовый фонд Международного уголовного суда, может, в соответствии со статьей 79(1) Римского статута, быть образован по решению Ассамблеи государств-участников, в пользу потерпевших от преступления, находящегося в

\footnotetext{
${ }^{38}$ Ст. 79 (2). Римского статута.

${ }^{39}$ Ст.75 (4-5), 93 (1) и 109, а также Правила 217, 218 и 221.

${ }^{40}$ См. также Правило 99.

${ }^{41}$ UN Doc. A/56/495/Add. 1, pars. 2 и 79.
} 
пределах полномочий Суда, а также в пользу семей пострадавших. Дело в том, что многие лица, бывшие обвиненными в трибуналах $a d$ hoc, оказались не в состоянии оплачивать защитников для себя, и защитники были выделены для них трибуналами. Трудности обнаружения имущества обвиняемых иллюстрируется, в частности, тем фактом, что Трибуналу по бывшей Югославии пришлось создать специальное подразделение по обнаружению финансов в отношении некоторых высоко поставленных обвиняемых. Вообще же функцию установления финансового положения обвиняемых, объявляю.щих себя несостоятельными, несет Офис секретаря подразделения по вопросам юридической помощи.

В рамках Трибунала по Руанде также была создана Группа отслеживания, одна из функций которой - «устанавливать местонахождение имущества обвиняемых и их пособников, а также принимать меры к его сохранности, с тем, чтобы в дальнейшем это имущество могло быть использовано для выплаты возмещений пострадавшим в соответствии с Правилом $105 »^{42}$. Прокурор трибуналов $a d$ hoc неоднократно утверждал, что его офис «достиг значительных успехов в обнаружении и замораживании больших денежных сумм на персональных счетах обвиняемых» ${ }^{43}$.

\section{Трастовый фонд Международного уголовного} суда в интересах пострадавщих от преступлений в пределах юрисдикичии МУС

В Римском статуте структура Фонда не определена. В нем фактически более или менее установлено два источника доходов для Трастового фонда, а именно:

1. Суд может принять постановление о возмещении имуществом обвиняемого через Трастовый фонд;

2. Суд может распорядиться о том, денежные средства и иное имущество, полученное от штрафов или конфискации, должны быть переданы в Трастовый фонд ${ }^{44}$.

Трастовый фонд, в свою очередь, должен управляться в соответствии с критериями, уста-

${ }^{42}$ UN Doc. A/55/512, p. 48 (par. 42).

${ }^{43}$ ICTY Doc. Press Release JL/P.I.S./542-e.

${ }^{44}$ Статьи 75 и 79 Римского статута. новленными Ассамблеей государств-участников $^{45}$. Некоторые правила процедуры Суда также относятся к функционированию Фонда.

В Римском статуте предусмотрено, что Трастовый фонд функционирует и как посредник, если Суд решает, что возмещение будет произведено через Фонд, и как депозитарий или доверенное лицо, если Суд решает передать Фонду средства, собранные от штрафов или конфискации.

В резолюции Ассамблеи государств-участников предусмотрено еще два дополнительных источника финансирования Фонда, причем Фонд в этих случаях играет роль депозитария:

1. добровольные взносы правительств, международных организаций, отдельных лиц, корпораций и т.д.;

2. такие ресурсы, кроме указанных взносов, которые Ассамблея государств-участников может выделить Трастовому фонду ${ }^{46}$.

Кроме того, Правилами Фонду отведена роль экспертного органа, который может давать консультации перед принятием решений относительно возмещения ${ }^{47}$.

В одной из своих резолюций Ассамблея государств-участников предусмотрела создание Совета директоров для Трастового фонда. В соответствии с Резолюцией, Совет состоит из пяти членов, избираемых на срок 3 года и могут переизбираться один раз. Члены Совета должны быть гражданами разных государств по принципу справедливого географического представительства с учетом справедливого гендерного распределения и справедливого представительства основных юридических систем мира. Эти люди также должны иметь высокие моральные качества и быть компетентными в вопросах помощи жертвам тяжелых преступлений ${ }^{4}$. Там же содержалась просьба к Совету разработать предложения относительно дальнейших критериев управления Фондом, которые были бы рассмотрены и приняты Ассамблеей государств-участников. В этой же резолюции перед Советом поставлена задача организовать и направлять деятельность Фонда, особенно в части конкретных проектов и

\footnotetext{
${ }^{45}$ Статья 79(3).

${ }^{46}$ ICC Doc. Resolution ICC-ASP/1/Res.6.

${ }^{47}$ Правила 148 и 221.

${ }^{48}$ ICC Doc. Resolution ICC-ASP/1/Res. 6.
} 
распределения имущества и денежных средств, имея в виду имеющиеся ресурсы с тем, чтобы строго следовать решениям Суда. Наконец, презюмируется, что Совет одобряет или отвергает добровольные взносы, направляемые правительствами, международными организациями, отдельными лицами, корпорациями и т.п. ${ }^{49}$

Согласно резолюции, Совет отвергает взносы в двух случаях:

1. если эти взносы не соответствуют целям и обычной деятельности Трастового фонда;

2. если лицо, дающее взнос, просит использовать его определенным образом, и исполнение данной просьбы приведет к явно несправедливому распределению имеющихся средств и имущества между различными группами пострадавших ${ }^{50}$.

Связь между Трастовым фондом и Международным уголовным судом установлена пунктом 5 резолюции, в котором сказано: «Секретарь Суда несет ответственность за предоставление такой помощи, которая необходима для надлежащего функционирования Совета по исполнению стоящих перед ним задач и также участвует в заседаниях Совета с правом совещательного голоса». Некоторые международные неправительственные организации критикуют идею участия одного из органов Суда в деятельности Трастового фонда, поскольку они считают, что это затруднит предоставление Фоном содействия пострадавшим, не задействованным в конкретном разбирательстве, и вообще сделает Фонд менее независимым ${ }^{51}$.

Что касается посреднической роли Фонда, в Правиле 98 предусмотрено, что Суд может распорядиться о том, чтобы суммы, причитающиеся как выплаты возмещения со стороны обвиняемого, были внесены в Трастовый фонд, в тех случаях, когда невозможно или затруднительно выплачивать индивидуальные суммы непосредственно каждому пострадавшему. Суммы, таким образом депонированные в Трастовом фонде, отделяются

${ }^{49}$ ICC Doc. Resolution ICC-ASP/1/Res. 6. See also ICC Doc. Resolution ICC-ASP/1/Res. 7.

${ }^{50}$ ICC Doc. Resolution ICC-ASP/1/Res. 6.

${ }^{51}$ The European Law Students' Association Report, The Preparatory Commission foe the International Criminal Court, $10^{\text {th }}$ Session, 1-12 July 2002. p. 26. от других ресурсов Фонда, и передаются каждому пострадавшему в возможно короткий срок.

Суд может также постановить, чтобы возмещения производились через Трастовый фонд, если число пострадавших, а также объем, формы и методы выплаты возмещения делают коллективный подход более практичным. Постановление Суда может также касаться выплат через Трастовый фонд, если речь идет о выплатах в адрес межгосударственных, неправительственных или национальных организациях, одобренных Фондом (Правило 98). Такие организации могут быть более подходящим инструментом для распределения возмещений особенно в тех случаях, когда выплаты производятся в коллективном порядке. В целом, как представляется, Правила отдают предпочтение прямым выплатам от преступника пострадавшим в случаях индивидуальных выплат, и косвенным выплатам (например, через Фонд) в случаях коллективных выплат.

Если Трастовый фонд действует в качестве посредника, у него нет юридического права на имущество, находящееся в трасте в интересах другого лица, то есть он не действует как доверенное лицо. Формулировка статьи 75.2 ясно указывает, что возмещение может быть присуждено постановлением Суда к осуществлению через Трастовый фонд, а не для Фонда. Это означает, что Фонд никогда не приобретает proprietary права собственности на возмещение, присужденное пострадавшим. Он просто действует как посредник. Следовательно, хотя Фонд может использовать суммы, полученные от штрафов и forfeiture, в любых целях, которые он считает содействующими интересам пострадавших, суммы, предназначенные постановлением Суда для возмещения, имеют иной характер. Трастовый фонд обязан распределить эти суммы только среди пострадавших от действий конкретного преступника, в тех формах и в те сроки, которые определены Судом.

Функции доверенного лица выполняются Фондом только в тех случаях, когда он действует в качестве депозитария. Более того, будучи посредником, он расценивается просто как «инструмент в руках Суда», поскольку именно Суд наделен полномочиями распределять фонды. Если же Фонд действует как депозитарий, тогда Суд не распоряжается распределением средств. 
Международный уголовный суд вправе, кроме тюремного заключения, постановить о конфискации имущества, приобретенного прямо или косвенно в результате преступления, а также о наложении штрафа ${ }^{52}$. Это имущество может быть позднее распоряжением Суда передано Трастовому фонду, который затем станет действовать как депозитарий ${ }^{53}$. Есть мнение о том, что, вынеся постановление о штрафе или конфискации, Суд может решить о передаче соответствующих сумм Трастовому фонду. Однако есть серьезные основания для использования их исключительно в интересах пострадавших, а не для возмещения оперативных расходов Суда ${ }^{54}$. Очевидно, под серьезными основаниями имеется в виду история формулирования данной статьи, а также тот факт, что суммы, полученные от штрафов и конфискации, не включены в список источников финансирования. Отметим также Правило 221 (2) МУС: «Во всех случаях, когда Президентство решает о помещении куда-либо или о распределении имущества или средств, принадлежащих лицу, в отношении которого вынесен приговор, Президентство отдает приоритет исполнению мер, касающихся возмещения потерпевшим».

Прежде чем выносить распоряжение о такой передаче, Палата может запросить соответствующие соображения об этом представителей Фонда в письменном или устном виде $\mathrm{e}^{55}$. Правда, Статут и Правила процедуры не устанавливают прямо распределение обязанностей после того, как произведена передача средств, а именно, Суд или сам Фонд будут распоряжаться их дальнейшей судьбой. Единственное положение об этом - статья 79(1), которая определяет, что Фонд создается «в интересах жертв преступлений, подпадающих под юрисдикцию Суда, и семей таких жертв». Правило 98(5) устанавливает, что иные ресурсы Фонда, кроме сумм, предназначенных для возмещения, могут использоваться в интересах пострадавшего в соответствии со

\footnotetext{
${ }^{52}$ Статья 77(2).

${ }^{53}$ Статья 79(2).

${ }^{54}$ См., напр.,: Ingadottir T. The International Criminal Court, the Trust Fund for Victims (Article 79 of the Rome Statute): A Discussion Paper, ICC Discussion Paper \# 3.14 November 2001.

${ }^{55}$ Правило 148.
}

статьей 79. «Иные ресурсы Фонда», кроме штрафов и и сумм от конфискации, состоят из добровольных взносов правительств, международных организаций, индивидов, корпораций и т.п., и такие ресурсы , по возможному постановлению Ассамблеи государств-участников, могут быть переданы Трастовому фонду. Именно Ассамблея может принять более детализированные нормы относительно использования ресурсов, депонированных в Фонде ${ }^{56}$.

\section{Заключение}

Существует практически всеобщее согласие относительно того, что жертвы серьезных международных преступлений имеют право на возмещение. Разногласия вызывает право, и особенно объем этого права, международных уголовных трибуналов на решение вопроса о предоставлении пострадавшим возмещения. Особенностью тяжелых международных преступлений является большое число пострадавших и крайняя степень наносимого им вреда. Кроме того, часто довольно трудно расследовать обстоятельства нанесения вреда, во время, например, вооруженного конфликта, что осложняет и судебное разбирательство.

Международные уголовные трибуналы $a d$ hoc и Международный уголовный суд подходят к вопросу о возмещениях очень по-разному. Действующие ныне международные уголовные трибуналы ad hoc не выносят постановлений о возмещении пострадавшим. Трибуналы не могут предоставить пострадавшим компенсации, и не занимаются реституцией собственности. Причины здесь чисто практического свойства. Утверждается, например, что рассмотрение вопроса о репарациях сильно затягивало бы процесс, в то время как есть гораздо более скорые методы. Кроме того, судьи этих трибуналов поддерживают идею о том, что поскольку каждому присудить компенсацию невозможно, не следует компенсировать никого. Некоторые авторы, особенно из стран common law, подчеркивают, однако, что такой по существу уголовный суд, как эти трибуналы, и не может иметь развитой системы процедур возмещения, в которых бы потерпев-

\footnotetext{
${ }^{56}$ Статья 79 (3).
} 
шие могли играть активную роль. По их мнению, активное участие потерпевших создает угрозу личным правам обвиняемого на справедливое разбирательство, поскольку нарушает равновесие между обвинением и защитой.

Трибуналы ad hoc в целом стали именно на эту точку зрения и потому не допускают представления пострадавшими гражданских исков в уголовном процессе. Тогда, с точки зрения пострадавших, трибуналы ad hoc не составляют часть такой же сложной системы уголовного правосудия, как национальные уголовные суды, и это означает, что пострадавшие обладают весьма узкими возможностями для успешного обращения за возмещением. В странах common law пострадавшие нередко получают возмещение на основании постановления суда, или через государственные органы. Пострадавшим, проходящим через процесс в международном уголовном трибунале, такие схемы недоступны.

Международный уголовный суд, с другой стороны, способен обеспечивать пострадавших компенсациями, то есть у него несколько гражданско-правовой подход к вопросу о возмещениях. Суд может решить о предоставлении возмещения, а пострадавшим предоставлены права участия в процессе в том, что касается рассмотрения вопроса о возмещении.

Некоторые утверждают, что трибуналам $a d$ hoc, в отличие от постоянного международного суда, надлежит скорее полагаться на внутригосударственные процедуры возмещения: «Международный уголовный суд будет иметь дело только с теми делами, в которых внутреннее уголовное правосудие обнаружило свои нежелание или неспособность осуществить судебное преследование. В таких ситуациях вероятно, что и получение возмещения на внутригосударственном уровне невозможно» ${ }^{57}$.

Возмещение может иметь разные формы, в том числе индивидуальные и коллективные возмещения. И хотя в документах МУС содержатся многочисленные положения относительно роли суда в определении возмещений, все же следует

${ }^{57}$ McKay F. Are Reparations Approprietly addressed in the ICC Statute?//D.Shelton (ed.) International Crimes, Peace and Human Rights: the Role of the International Criminal Court, 2000, p.164. ожидать, что многие практические проблемы будут решаться в процессе судебной практики.

Во-первых, перед судом, очевидно, встанут некоторые проблемы, порождаемые природой тяжких международных преступлений. Такие преступления нередко характеризуются участием в них множества преступников из разных слоев общества, множества потерпевших и исключительная жестокость. По мнению некоторых авторов, эти особенности международных преступлений недостаточно учтены учредительными документами МУС, особенно в связи с вопросом о возмещениях. Как пишет К.МакКарти, основные документы Суда не учитывают значение различной степени индивидуальной ответственности за одно и то же преступление в связи с обязанностью предоставить компенсации. Поэтому потерпевшим и их представителям неясно, кому они должны адресовать свои иски о возмещениях. В частности, сомнительно, чтобы потерпевшие, не получившие полного возмещения от осужденного лица, в дальнейшем направили иски в адрес другого лица, например, в адрес его командира, который несет ответственность за совершение того же преступления. Очевидно, Суд неизбежно будет откладывать оценку того, как должно быть распределено бремя возмещения, до тех пор, пока не состоится разбирательство в отношении всех виновных в одном преступлении ${ }^{58}$.

Можно не соглашаться с выводами автора, однако ясно, что им поставлена реальная проблема. Индивидуальную ответственность за предоставление возмещения трудно определить. В связи с этим разбирательство по вопросу о возмещениях могло бы быть полностью парализовано, поскольку преступники, связанные одним преступлением, могут быть действительно многочисленными, так что невозможно будет арестовать всех одновременно или в каком-либо другом порядке. С точки зрения пострадавшего, вернее было бы судить преступников, которые предоставили полное возмещение, позднее, когда за это же самое преступление будут приговорены другие лица, и от них также можно будет потребовать выплаты возмещения.

\footnotetext{
${ }^{58}$ McCarthy C. Reparations and Victim Support in the International Criminal Court. 2012, p.138.
} 
Не так легко для Суда и решить, кто из потерпевших имеет приоритетное право на возмещение, если имеющиеся для этого ресурсы не так велики, а потерпевших множество. Ингадоттир, например, ставит вопрос о том, будет ли Суд отдавать предпочтение потерпевшим физическим или юридическим лицам ${ }^{59}$. Возможно также задать вопрос более общего характера: кому из потерпевших Суд будет отдавать предпочтение, если перед ним встанет такая задача. Поскольку МУС рассматривает только дела о самых тяжких преступлениях, выбирать приоритеты - чрезвычайно трудная задача. Нехватка ресурсов также будет влиять на формы присуждаемого возмещения, например, будет принуждать к групповому возмещению.

Наконец, нельзя забывать о том, что многочисленность потерпевших будет скорее всего подталкивать Суд к использованию специальных процедур, с тем, чтобы не нарушать права обвиняемых, в частности, их права на рассмотрение дела без промедления. К.МакКарти считает, что Международному уголовному суду следует присмотреться к методам, используемым
Компенсационной комиссией ООН, которая занималась вопросами возмещения в связи с вторжением Ирака в Кувейт. Она также считают полезным создание комиссии экспертов, которая бы оказывала содействие судьям в решении вопросов возмещения, с тем, чтобы сократить его занятость ${ }^{60}$.

Кроме того, внимание Суда может быть привлечено к опыту Палаты по правам человека для Боснии и Герцеговины, в частности, в разбирательстве в делах Srebrenica, где Палата присудила групповые возмещения ${ }^{61}$.

Во-вторых, в процедуре рассмотрения вопроса о возмещении есть несколько пробелов, которые МУСу придется заполнять в ходе практики. Как уже отмечалось, стандарты доказывания в том, что касается возмещения, остались без регулирования в основных документах суда. Таким образом, у Суда есть все возможности, благодаря незавершенному регулированию, разработать собственную практику относительно возмещения пострадавшим. С точки зрения пострадавших остается надеяться, что у Суда будет достаточно ресурсов для обеспечения значимых репараций пострадавшим.

\section{Библиография:}

1. Donat-Cattin D.Article 75 - Reparations to Victims//Triffterer O. Commentary on the Rome Statute of the International Criminal Court: Oserver's Notes Article by Article. 1999, pp. 969-970.

2. McCarthy C. Reparations and Victim Support in the International Criminal Court. 2012, p.138.

3. McKay F. Are Reparations Approprietly addressed in the ICC Statute?//D. Shelton (ed.) International Crimes, Peace and Human Rights: the Role of the International Criminal Court, 2000, p.164.

4. Ingadottir T. The International Criminal Court, the Trust Fund for Victims (Article 79 of the Rome Statute): A Discussion Paper, ICC Discussion Paper \# 3.14 November 2001.

5. Смбатян А.С. Процессуальные решения в рамках неотъемлемой и подразумеваемой компетенции ОРС ВТО//Международное право и международные организации, № 2 (10), 2012. С. 113.

6. Г.Г. Шинкарецкая. Изъятие из компетенции судебных учреждений дел, относящихся к внутренней компетенции государства // Право и политика. - 2010. - № 3.

7. Г.Г. Шинкарецкая. Запрет злоупотребления международной судебной процедурой как фактор обеспечения судебного процесса // Право и политика. - 2010. - № 2.

8. Р.А. Каламкарян, Ю.И. Мигачев. Всеобщая Декларация прав человека: роль и значение в условиях миропорядка на основе господства права Rule of Law. // Право и политика. - 2008. - № 12. - С. 104-107.

9. Р.А. Каламкарян. Всеобщая декларация прав человека-60 лет. Позитив международно-правового опыта. // Право и политика. - 2008. - №

${ }^{59}$ Ingadottir T. Op.cit, p. 10.

\footnotetext{
${ }^{60}$ Mc Carthy C. Op.cit, p.368.

${ }^{61}$ Human Rights Chamber for Bosnia Herzegovina, cases CH/01/8365 et al., pars. 214-218.
} 
10. Ерпылева Н.Ю. Международный коммерческий арбитраж: правовые основы функционирования // NB: Международное право. - 2013. - № 1. - C.1-74. DOI: 10.7256/2306-9899.2013.1.545. URL: http://e-notabene.ru/wl/article_545.html

11. Р. А. Каламкарян. Международный уголовный суд. // Право и политика. - 2002. - № 6. Каламкарян P.А. Роль Международного Суда ООН в деле поддержания международного правопорядка // NB: Международное право. - 2013. - № 1. - C.184-214. DOI: 10.7256/2306-9899.2013.1.690. URL: http://enotabene.ru/wl/article_690.html

12. Каламкарян Р.А. Включенность Российской Федерации в деятельность Международного Суда ООН в деле обеспечения международной законности и правопорядка // NB: Международное право. 2013. - № 2. - C.85-118. DOI: 10.7256/2306-9899.2013.2.691. URL: http://e-notabene.ru/wl/article_691.html

13. Ранчинская П.О.. Специфика взаимодействия российского и международного права в области международного коммерческого арбитража // Право и политика. - 2013. - № 10. - C. 104-107. DOI: 10.7256/1811-9018.2013.10.9581.

14. А.С. Смбатян. Перспективы суда ЕврАзЭС в системе органов международного правосудия // Международное право и международные организации / International Law and International Organizations. - 2013. - № 1. - C. 104-107. DOI: 10.7256/2226-6305.2013.01.7.

15. Р. А. Каламкарян. Международный суд ООН как административно-правовой орган мирового сообщества по мирному разрешению международных споров // Международное право и международные организации / International Law and International Organizations. - 2011. - № 2

16. Сазонова К.Л. К вопросу о соотношении международных преступлений государства, норм јus cogens и обязательств erga omnes в современном международном праве // Право и политика. 2013. - 9. - C. 1175-1181. DOI: 10.7256/1811-9018.2013.9.9410.

17. Р. А. Гурбанов Европейская судебная сеть и Евроюст как основные субъекты сотрудничества органов правосудия государств-членов ЕС в сфере уголовного правосудия. // Международное право и международные организации / International Law and International Organizations. - 2011. - 4. - С. 113-120.

18. В. А. Оганесян Решения международных судов по правам человека как особый источник развития и соблюдения принципов уголовного правосудия // Международное право и международные организации / International Law and International Organizations. - 2012. - 1. - C. 65-7

\section{References (transliteration):}

1. Donat-Cattin D.Article 75 - Reparations to Victims//Triffterer O. Commentary on the Rome Statute of the International Criminal Court: Oserver's Notes Article by Article. 1999, pp. 969-970.

2. McCarthy C. Reparations and Victim Support in the International Criminal Court. 2012, r.138.

3. McKay F. Are Reparations Approprietly addressed in the ICC Statute?//D.Shelton (ed.) International Crimes, Peace and Human Rights: the Role of the International Criminal Court, 2000, p.164.

4. Ingadottir T. The International Criminal Court, the Trust Fund for Victims (Article 79 of the Rome Statute): A Discussion Paper, ICC Discussion Paper \# 3.14 November 2001.

5. Smbatyan A.S. Protsessual'nye resheniya v ramkakh neot'emlemoi i podrazumevaemoi kompetentsii ORS VTO//Mezhdunarodnoe pravo i mezhdunarodnye organizatsii, № 2 (10), 2012. S. 113.

6. G.G. Shinkaretskaya. Iz"yatie iz kompetentsii sudebnykh uchrezhdenii del, otnosyashchikhsya k vnutrennei kompetentsii gosudarstva // Pravo i politika. - 2010. - № 3.

7. G.G. Shinkaretskaya. Zapret zloupotrebleniya mezhdunarodnoi sudebnoi protseduroi kak faktor obespecheniya sudebnogo protsessa // Pravo i politika. - 2010. - № 2.

8. R.A. Kalamkaryan, Yu.I. Migachev. Vseobshchaya Deklaratsiya prav cheloveka: rol' i znachenie v usloviyakh miroporyadka na osnove gospodstva prava Rule of Law. // Pravo i politika. - 2008. - № 12. - S. 104-107.

9. R.A. Kalamkaryan. Vseobshchaya deklaratsiya prav cheloveka-60 let. Pozitiv mezhdunarodno-pravovogo opyta. // Pravo i politika. - 2008. - № 
10. Erpyleva N.Yu. Mezhdunarodnyi kommercheskii arbitrazh: pravovye osnovy funktsionirovaniya // NB: Mezhdunarodnoe pravo. - 2013. - № 1. - S.1-74. DOI: 10.7256/2306-9899.2013.1.545. URL: http://e-notabene.ru/wl/article $545 . \mathrm{html}$

11. R. A. Kalamkaryan. Mezhdunarodnyi ugolovnyi sud. // Pravo i politika. - 2002. - № 6. Kalamkaryan R.A. Rol' Mezhdunarodnogo Suda OON v dele podderzhaniya mezhdunarodnogo pravoporyadka // NB: Mezhdunarodnoe pravo. - 2013. - № 1. - S.184-214. DOI: 10.7256/2306-9899.2013.1.690. URL: http://e-notabene.ru/wl/article_690.html

12. Kalamkaryan R.A. Vklyuchennost' Rossiiskoi Federatsii v deyatel'nost' Mezhdunarodnogo Suda OON v dele obespecheniya mezhdunarodnoi zakonnosti i pravoporyadka // NB: Mezhdunarodnoe pravo. - 2013. - № 2. - S.85-118. DOI: 10.7256/2306-9899.2013.2.691. URL: http://e-notabene.ru/wl/article_691.html

13. Ranchinskaya P.O.. Spetsifika vzaimodeistviya rossiiskogo i mezhdunarodnogo prava v oblasti mezhdunarodnogo kommercheskogo arbitrazha // Pravo i politika. - 2013. - № 10. - S. 104-107. DOI: 10.7256/1811-9018.2013.10.9581.

14. A.S. Smbatyan. Perspektivy suda EvrAzES v sisteme organov mezhdunarodnogo pravosudiya // Mezhdunarodnoe pravo i mezhdunarodnye organizatsii / International Law and International Organizations. - 2013. - № 1. - S. 104-107. DOI: 10.7256/2226-6305.2013.01.7.

15. R. A. Kalamkaryan. Mezhdunarodnyi sud OON kak administrativno-pravovoi organ mirovogo soobshchestva po mirnomu razresheniyu mezhdunarodnykh sporov // Mezhdunarodnoe pravo i mezhdunarodnye organizatsii / International Law and International Organizations. - 2011. - № 2

16. Sazonova K.L. K voprosu o sootnoshenii mezhdunarodnykh prestuplenii gosudarstva, norm jus cogens i obyazatel'stv erga omnes v sovremennom mezhdunarodnom prave // Pravo i politika. 2013. - 9. - C. 1175-1181. DOI: 10.7256/1811-9018.2013.9.9410.

17. R. A. Gurbanov Evropeiskaya sudebnaya set' i Evroyust kak osnovnye sub"ekty sotrudnichestva organov pravosudiya gosudarstv-chlenov ES v sfere ugolovnogo pravosudiya. // Mezhdunarodnoe pravo i mezhdunarodnye organizatsii / International Law and International Organizations. - 2011. - 4. - C. 113-120.

18. V. A. Oganesyan Resheniya mezhdunarodnykh sudov po pravam cheloveka kak osobyi istochnik razvitiya i soblyudeniya printsipov ugolovnogo pravosudiya // Mezhdunarodnoe pravo i mezhdunarodnye organizatsii / International Law and International Organizations. - 2012. - 1. - C. 65-7 